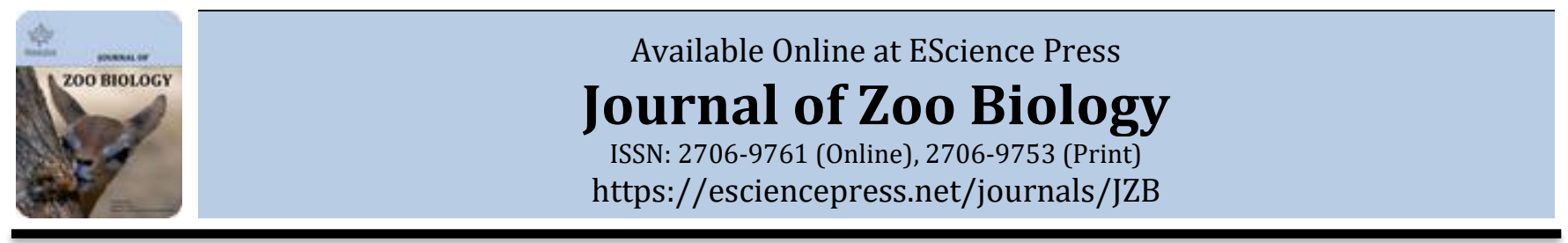

\title{
USE OF DIAZEPAM-KETAMINE IN PREVENTION OF CAPTURE MYOPATHY IN THE OSTRICH (STRUTHIO CAMELUS): A CASE REPORT
}

aVeronica Adetunji, bJohn Ogunsola*

a Department of Veterinary Public Health and Preventive Medicine, University of Ibadan, Ibadan, Nigeria.

b Veterinary Teaching Hospital, University of Ibadan, Ibadan, Nigeria.

*Corresponding Author Email ID: ogunsolajo@yahoo.com

\section{A B S T R A C T}

Capture or exertional myopathy is an attendant complication of manual restraint in ratites, asides physical injuries that handlers may suffer. This work was carried out to restrain and immobilize two ostriches (Struthio camelus) in a bid to facilitate their clinical examination and transportation from one location to another, without subjecting the birds to capture myopathy that arises from the stress and exertion associated with physical restraint and capture. Two ostriches, male and female, weighing $120 \mathrm{~kg}$ and $105 \mathrm{~kg}$ respectively, were requested to be immobilized for relocation from Onireke to Jericho area in Oyo State, Nigeria. The birds were fasted overnight, administered with diazepam $(3 \mathrm{mg} / \mathrm{kg})$ orally and ketamine $(10 \mathrm{mg} / \mathrm{kg})$ intramuscularly. Mild sedation was achieved with diazepam after one hour. The birds were successfully transported. Complete recovery was achieved at about 8hours postadministration of ketamine. Anaesthetic agents did not alter the haematologic parameters. We conclude that the diazepam-ketamine combination is generally safe for ratites and that oral administration of diazepam accompanied by intramuscular administration of ketamine provides restraint in ratites while also avoiding the risk of capture myopathy. It is suggested that the current dose of diazepam might need to be increased if the oral route is to be employed so as to shorten the onset of sedation and increase the depth of sedation.

Keywords: Capture myopathy, chemical restraint, ostrich.

\section{INTRODUCTION}

In the recent past, ostrich farming has increased globally and has become a recent worldwide economic activity (Carrer and Kornfeld, 1999). The ostrich (Struthio camelus) is the largest bird in the world with the adult measuring as much as 2.75meters in height and weighing as much as 150 kilograms (Huchzermeyer, 2000) and belongs to the ratite family of birds that comprises running birds. Their extreme visual acuity and open habitat make them difficult to approach undetected. Also, as a result of the size, speed and powerful kicking ability of the adult birds, chemical immobilization and general anaesthesia are usually made use of in these animals to provide veterinary care (Al-Sobayil and Omer, 2011). They are highly susceptible to stress caused by physical methods of restraint (Cornick-Seahorn, 1996).

Knowledge about ratite anaesthesia refers mostly to non-captive or zoo animals, in contrast to little information available from ostriches reared in commercial production systems (Cornick-Seahorn, 1996). In commercial rearing, chemical restraints and interventions are needed in many procedures such as sample collection and picking of feathers (Ostrowski and Ancrenaz, 1995) and in some minor surgical procedures such as suturing and placement of oesophageal probe and intubation (Cornick and Jensen, 1992). The induction of anaesthesia in ratites has been performed both IM and IV, and also by using inhalation anaesthesia (Cornick-Seahorn, 1996). However, ratite anaesthetic events are often dangerous because these birds use their powerful legs and clawed feet as a defence, and physical restraint can result in self-trauma or injury to handlers. Capture myopathy (CM), also known as exertional myopathy (Williams, 1996), is an important complication of capture and handling in many species of wild mammals and birds. The stress, struggling, and exertion due to pursuit and capture is thought to create 
a physiologic cascade with hyperthermia, anaerobic glycolysis, metabolic acidosis, reduced tissue perfusion, and hypoxia (Spraker, 1993), resulting in myocellular necrosis in cardiac and skeletal muscles. Reduced muscle function leads to ataxia, weakness, and partial or complete paralysis. Renal failure, circulatory collapse, and death may occur in severe cases (Williams, 1996). Some animals appear to recover, only to die suddenly days or weeks later following a further stressful or exertive event (Spraker, 1993). There are few published reports of successful treatment of CM in wild birds e.g. (Businga et al., 2007; Rogers et al., 2004; Smith et al., 2005) and the focus remains on prevention (Williams, 1996). An extensive work on various agents that could produce anaesthesia and chemical restraint in ratites has been reported (Speer, 2006).

This work was carried out in order to screen the ostriches for blood and faecal parasites, to determine their blood chemistry and to facilitate their transportation from one location to another without subjecting the birds to capture myopathy that arises from the stress and exertion associated with physical restraint and capture.

\section{METHODOLOGY}

Two ostriches, male and female, weighing $120 \mathrm{~kg}$ and $105 \mathrm{~kg}$ respectively, were requested to be immobilized for relocation from Onireke to Jericho area in Oyo State, Nigeria. The ratites were fasted overnight. Diazepam (Valium; SwissPharm, Nigeria) was administered orally through the feed at the rate of $3 \mathrm{mg} / \mathrm{kg}$ body weight.
After one hour, with some degree of manual restraint, the birds were examined, blood samples were obtained from the femoral vein, faecal samples were obtained and then ketamine hydrochloride [Ketamine; Rotex Medica, Germany] was administered at $10 \mathrm{mg} / \mathrm{kg}$ body weight intramuscularly. Birds were later transported via road transported from Onireke to Jericho area.

\section{RESULTS}

A. Physical response to Anaesthetic Protocol: The birds required a little over an hour post-diazepam administration before mild sedation was noticed. Although reduced, a measure of physical restraint was needed to examine the birds, obtain blood and faecal samples as well as intramuscular administration of ketamine.

B. Physical Examination: Both birds were in apparent good body condition, alert and active. However, the ocular mucous membrane of the male was moderately pale (suggestive of anaemia). The cloaca of the male contained a very scant amount of faeces, thereby making it impossible to obtain a faecal sample from the male.

C. Clinicopathologic Findings: The haematologic findings are presented in Tables 1 . Notably, the erythrocyte and leukocyte indices of the male revealed a moderate anaemia $(\mathrm{PCV}=23 \%)$, leucopenia $(\mathrm{TWCC}=$ $2,600 / \mathrm{uL}$ ) as well as a mild hypoproteinemia.

D. Parasitologic Findings: Faecal sample, obtained from the female, was reported as negative for helminth ova and protozoan cysts.

Table 1. Haematologic parameters of two (2) ostriches.

\begin{tabular}{|c|c|c|c|c|c|c|c|c|c|c|c|c|c|}
\hline Sr. & Sex & $\begin{array}{c}\text { PCV } \\
\%\end{array}$ & $\begin{array}{c}\mathrm{RBC} \\
\mathrm{x} 10^{6} / \mathrm{ul}\end{array}$ & $\begin{array}{l}\mathrm{Hb} \\
\mathrm{g} / \mathrm{dl}\end{array}$ & $\begin{array}{c}\mathrm{MCV} \\
\mathrm{fl}\end{array}$ & $\begin{array}{c}\mathrm{MCHC} \\
\text { pg }\end{array}$ & $\begin{array}{c}\text { PLT } \\
\text { X106/ul }\end{array}$ & $\begin{array}{c}\text { TWCC } \\
/ \mathrm{ul}\end{array}$ & $\begin{array}{l}\mathrm{H} \\
\%\end{array}$ & $\begin{array}{l}\mathrm{L} \\
\%\end{array}$ & $\begin{array}{l}\mathrm{M} \\
\%\end{array}$ & $\begin{array}{l}\mathrm{E} \\
\%\end{array}$ & $\begin{array}{c}\mathrm{TP} \\
\mathrm{g} / \mathrm{dl}\end{array}$ \\
\hline 1. & $\mathrm{~F}$ & 40 & 10.24 & 13.2 & 39 & 33 & 12 & 5400 & 24 & 76 & 0 & 0 & 6.2 \\
\hline 2. & M & 23 & 6.42 & 7.7 & 35 & 33 & 08 & 2600 & 25 & 74 & 1 & 0 & 3.4 \\
\hline
\end{tabular}

TWCC: total white cell count; H: heterophils; L: lymphocyte; M: monocyte; E: eosinophil TP: total protein.

\section{DISCUSSION AND CONCLUSION}

Restraint is imperative in the handling, examination, immobilization and transportation of ostriches. Manual restraint is particularly associated with exertional/ capture myopathy (CM) to the birds as well as varying degrees of physical injuries to unsuspecting handlers. CM arises from a combination of stress and anaerobic glycolysis during handling. Treatment is not effective and the emphasis is placed on preventing its occurrence and thus the need for chemical restraint.

With good facilities, such as a dart gun, delivering chemical agents is simple, precise and easy. However, in the absence of such facilities, administering chemical restraint may present a daunting task. In our case, we opted for sedation using the oral route before anaesthesia. To achieve this, the birds were fasted overnight. This action was important for three reasons. First, it was going to help empty/rest the gastrointestinal tract. Second, it would avoid aspiration pneumonia that may result from emesis which is a side effect of a few sedatives. Finally, we believed that fasting would stimulate the appetite and rate of consumption of 
a sedative-laden feed when presented to the birds.

The ease of oral administration of diazepam makes this technique a promising one. However, the prolonged onset of action and mild depth of sedation associated with the dose we used, in our opinion, is not satisfactory. Although a delay in the onset of action is expected when a drug is delivered per os, this may be compensated for by an increase in the administered dosage. The increase in dose will not only shorten the onset of action but also increase the depth of sedation. This increased depth of sedation may preclude the need for an anaesthetic (ketamine in this case) in a number of situations. These situations will include non-invasive procedures as well as interventions that are of sufficiently short duration. In our case, we believe that the diazepam-ketamine combination is generally safe. This is evidenced by the smooth, nonviolent recovery of the birds and the absence of any notable side-effects. We conclude that oral administration of diazepam and accompanied by intramuscular administration of ketamine provides restraint in ratites while also avoiding the risk of capture myopathy.

\section{REFERENCES}

Al-Sobayil, F. A. and O. H. Omer. 2011. Serum biochemical values of adult ostriches (Struthio camelus) anesthetized with xylazine, ketamine, and isoflurane. Journal of Avian Medicine and Surgery, 25: 97-101.

Businga, N. K., J. Langenberg and L. Carlson. 2007. Successful Treatment of Capture Myopathy in Three Wild Greater Sandhill Cranes (Grus Canadensis Tabida). Journal of Avian Medicine and Surgery, 21: 294-298.
Carrer, C. d. C. and M. E. Kornfeld. 1999. A criação de avestruzes no Brasil. Pirassununga, São Paulo: Ed. Ostrich do Brasil.

Cornick-Seahorn, J. 1996. Ratite management and surgery, in: TN, T., SM, S. (Eds.), Anesthesiology of Ratites. Krieger Publishing, Malabar.

Cornick, J. and J. Jensen. 1992. Anesthetic management of ostriches. Journal of the American Veterinary Medical Association, 200: 1661-1666.

Huchzermeyer, F. 2000. Doenças de avestruzes e outras ratitas. Jaboticabal: Funep.

Ostrowski, S. and M. Ancrenaz. 1995. Chemical immobilisation of red-necked ostriches (Struthio camelus) under field conditions. Veterinary Record, 136: 145-147.

Rogers, D. I., P. F. Battley, J. Sparrow, A. Koolhaas and C. J. Hassell. 2004. Treatment of capture myopathy in shorebirds: a successful trial in northwestern Australia. Journal of Field Ornithology, 75: 157-164.

Smith, K. M., S. Murray and C. Sanchez. 2005. Successful treatment of suspected exertional myopathy in a rhea (Rhea americana). Journal of Zoo and Wildlife Medicine, 36: 316-320.

Speer, B. 2006. Ratite Medicine and Surgery. The North American Veterinary Conference: 20.

Spraker, T. R. 1993. Stress and capture myopathy in artiodactylids. Zoo and wild animal medicine: 481-488.

Williams, E. S. 1996. Exertional myopathy (capture myopathy). Noninfectious Diseases of Wildlife.

Publisher's note: EScience Press remains neutral with regard to jurisdictional claims in published maps and institutional affiliations.

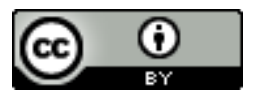

Open Access This article is licensed under a Creative Commons Attribution 4.0 International License, which permits use, sharing, adaptation, distribution and reproduction in any medium or format, as long as you give appropriate credit to the original author(s) and the source, provide a link to the Creative Commons license and indicate if changes were made. The images or other third-party material in this article are included in the article's Creative Commons license, unless indicated otherwise in a credit line to the material. If material is not included in the article's Creative Commons license and your intended use is not permitted by statutory regulation or exceeds the permitted use, you will need to obtain permission directly from the copyright holder. To view a copy of this license, visit http://creativecommons.org/licenses/by/4.0/.

(C) The Author(s) 2018. 